\title{
Production of Aminopeptidase and Carboxypeptidase by Streptomyces peptidofaciens ${ }^{\dagger}$
}

\author{
Takayuki Uwajima, Naohiro Yoshikawa and Osamu Terada \\ Tokyo Research Laboratory, Kyowa Hakko Kogyo, Ltd., Machidashi, Tokyo \\ Received October 5, 1972
}

\begin{abstract}
Streptomyces peptidofaciens $\mathrm{KY} 2389$, a new species isolated from a soil sample, exhibited the highest potencies in production of both aminopeptidase and carboxypeptidase among about 1,300 strains tested.

Optimum $\mathrm{pH}$ values of both aminopeptidase and carboxypeptidase for Leu- $\beta$-naphthylamide and $\mathrm{Cbz}$-Gly-Leu were 8.0. Aminopeptidase was thermostable and the activity was not lost by treatment at $70^{\circ} \mathrm{C}$ for $1 \mathrm{hr}$, in the presence of $\mathrm{Ca}^{2+}$. Carboxypeptidase was heatlabile and over $50 \%$ of the activity was lost by treatment at $60 \mathrm{C}$ for $1 \mathrm{hr}$. Of the synthetic peptides tested, Leu-Gly-Gly and Cbz-Gly-Leu were the most suitable substrates for aminopeptidase and carboxypeptidase, respectively.
\end{abstract}

Production of peptidases by microorganisms has been reported by many investigators. Especially, peptidases from Escherichia coli, ${ }^{1,}$ Bacillus subtilis, ${ }^{2}$ Aeromonas proteolytica, ${ }^{31}$ Phymatotrichum omnivorum ${ }^{4)}$ and Aspergillus saito ${ }^{5}$, were purified and their properties have been studied in detail.

As to actinomycetes, Narahashi et al. ${ }^{6}$ and Morihara et al. ${ }^{7}$ reported Streptomyces griseus and Streptomyces fradiae, respectively, capable of producing multiple proteolytic enzymes that include aminopeptidase and carboxypeptidase besides proteinases. Mizusawa et al. ${ }^{83}$ also reported that Streptomyces rectus var. proteolyticus produced carboxypeptidase as well as alkaline proteinase. However, these peptidases obtained from Streptomyces have not been homogeneous in the purities.

In the course of survey for microorganisms producing peptidases, we found that the culture filtrate of a newly isolated soil actinomycete, Streptomyces peptidofaciens, showed the highest hydrolytic activities toward Leu- $\beta$ naphthylamide and Cbz-Gly-Leu, but almost no caseinolytic activity.

In the previous communication, ${ }^{9}$ it has been

t Studies on Peptidase from Streptomyces. Part I. Abbreviations used are; Leu- $\beta$-naphthylamide: L-Leucyl- $\beta$-naphthylamide, Leu-Gly-Gly: L-Leucylglycyl-glycine, Cbz-Gly-Leu: Carbobenzoxy-glycylL-leucine. briefly reported that extracellular aminopeptidase of Streptomyces peptidofaciens was purified and crystallized by a procedure involving acetone precipitation, DEAE-cellulose and hydroxyapatite column chromatographies and Sephadex G-75 gel filtration. The present paper is concerned with the taxonomical study of Streptomyces peptidofaciens and some enzymatic properties of both aminopeptidase and carboxypeptidase.

\section{MATERIALS AND METHODS}

Microorganisms. Microorganisms tested in the present study were about 300 type cultures of various species in our culture collections and about 1000 cultures of Streptomyces which were newly isolated from soil samples.

Screening and media. An agar medium with the following composition was used for the isolation of Streptomyces : $0.3 \%$ soluble starch, $0.5 \%$ soy bean meal, $0.1 \%$ corn steep liquor, $0.05 \% \mathrm{~K}_{2} \mathrm{HPO}_{4}, 0.01 \%$ chloramphenicol and $2.0 \%$ agar (pH 7.6). Soil suspensions were streaked on the agar plates. After incubation at $27^{\circ} \mathrm{C}$ for 5 days, the Streptomyces grown on the plates were transferred to agar slants of the same medium. These cultures were inoculated into $50 \mathrm{ml}$ of the SBM-medium composed of $3 \%$ soluble starch, $5 \%$ soy bean meal, $0.5 \%$ corn steep liquor and $0.1 \%$ $\mathrm{Na}_{2} \mathrm{HPO}_{4}(\mathrm{pH} \mathrm{7.6)}$, in $250 \mathrm{ml}$ Erlenmeyer flasks and cultivated on a rotary shaker at $30^{\circ} \mathrm{C}$ for $48 \mathrm{hr}$. After the cultivation, aminopeptidase and carboxypeptidase 
activities of the culture filtrates were measured by using Leu- $\beta$-naphthylamide and Cbz-Gly-Leu as substrates, respectively.

Taxonomical studies. Streptomyces sp. KY 2389 was inoculated on various agar media conventionally used for the classification of Streptomyces and incubated for 4 weeks at $27^{\circ} \mathrm{C}$. The structure of spore was observed with an electron microscope. Utilization of carbon sources was determined by cultivation on Pridham and Gottlieb's media ${ }^{10)}$ which contain $1 \%$ of various carbon compounds.

Enzyme assays. The synthetic substrates used in these experiments were obtained from the Institute for Protein Research, Osaka University, Osaka.

The aminopeptidase activity was determined by a modified method of Goldberg and Rutenburg, ${ }^{11}$ using Leu- $\beta$-naphthylamide as substrate; $0.5 \mathrm{ml}$ of $6.8 \times 10^{-4} \mathrm{M}$ substrate and $0.5 \mathrm{ml}$ of the enzyme solution in $0.05 \mathrm{M}$ Veronal buffer ( $\mathrm{pH} 8.0$ ) containing $10^{-3} \mathrm{M}$ calcium acetate were mixed and incubated at $37^{\circ} \mathrm{C}$ for $20 \mathrm{~min}$. One aminopeptidase unit was defined as an amount of the enzyme that hydrolyzed $1 \mu$ mole of Leu- $\beta$-naphthylamide per minute under the conditions described.

The carboxypeptidase activity was determined by measuring the amounts of leucine liberated from Cbz-Gly-Leu after incubation at $40^{\circ} \mathrm{C}$ for $30 \mathrm{~min}$. The reaction mixture was composed of $0.5 \mathrm{ml}$ of $0.1 \mathrm{M}$ substrate and $0.5 \mathrm{ml}$ of the enzyme solution in $0.05 \mathrm{M}$ Veronal buffer ( $\mathrm{pH} 8.0$ ) containing $10^{-3} \mathrm{M} \mathrm{CoCl}_{2}$. Leucine was measured by the method of Yemm and Cocking. ${ }^{12\}}$ One carboxypeptidase unit was defined as an amount of the enzyme that hydrolyzed $1 \mu$ mole of Cbz-Gly-Leu per minute under the conditions described.

The proteinase activity was assayed at $\mathrm{pH} 7.0$ by the method of Hagihara et al. ${ }^{13 !}$ using milk casein as substrate and indicated by the absorbancy at $280 \mathrm{~m} \mu$.

Protein determination. Protein concentration was determined spectrophotometrically by measuring the absorbancy at $280 \mathrm{~m} \mu, \quad E_{1 \mathrm{~m}}^{1 \%}$ values of 16.4 and 15.0 for aminopeptidase and carboxypeptidase, respectively, were used throughout this work. The former was obtained by measurement of absorbance and by dry weight determinations. Specific activity was expressed in units of activity per $\mathrm{mg}$ of protein.

Sugar determination. Residual sugar in culture medium was determined by an improved Anthrone method of Loewus. ${ }^{14}$

Cell growth determination. Cell growth was determined by measuring solid volume: Ten $\mathrm{ml}$ of culture broth was centrifuged in a graduated tube at
$3000 \mathrm{rpm}$ for $10 \mathrm{~min}$ and solid volume was defined as the percent of the volume of sedimentary solid per $100 \mathrm{ml}$ of culture broth.

Purification procedures. Crystalline aminopeptidase was prepared from the culture filtrate of Streptomyces peptidofaciens KY 2389 grown on the SBM-medium, by procedures involving acetone precipitation, DEAEcellulose and hydroxyapatite column chromatographies, Sephadex G-75 gel filtration and addition of ammonium sulfate, as described previously. ${ }^{9)}$ The crystalline aminopeptidase was homogeneous on ultracentrifugation and electrophoresis.

Purified carboxypeptidase was prepared from the culture filtrate of $S$. peptidofaciens KY 2389, as follows. The fermentation broth ( 30 liters) was centrifuged with a continuous-flow separater and the supernatant fluid (27 liters), which contained about $45 \mathrm{~g}$ of protein and 5,100 units of carboxypeptidase activity, was concentrated 5 -fold in vacuo in a flash evaporater $\left(40^{\circ} \mathrm{C}\right)$. To 1 volume of the concentrated solution were added 2 volumes of acetone $\left(-15^{\circ} \mathrm{C}\right)$ and the resulting precipitate was collected by filtration and dissolved in the minimum volume of $0.05 \mathrm{M}$ acetate buffer ( $\mathrm{pH} 5.0$ ). This solution was dialyzed against 10 liters of the same buffer for $48 \mathrm{hr}$. The dialyzed enzyme solution $(350 \mathrm{ml})$, which contained $15.1 \mathrm{~g}$ of protein and 3,600 units of activity, was applied on Doulite $A-7$ resin column $(7.5 \times 65 \mathrm{~cm})$ equilibrated with $0.05 \mathrm{M}$ acetate buffer, ( $\mathrm{pH}$ 5.0). The enzyme was not adsorbed on the column under the conditions employed, but many inert materials including most of the black pigment were adsorbed and separated from the enzyme. The active fractions were combined and concentrated in vacuo in a rotary evaporater $\left(40^{\circ} \mathrm{C}\right)$. The concentrated carboxypeptidase fraction $(26 \mathrm{ml})$, which contained $980 \mathrm{mg}$ of protein and 1,100 units of activity, was subjected to gel filtration on a Sephadex G-75 column $(2 \times 100 \mathrm{~cm})$ equilibrated with $0.01 \mathrm{M}$ Veronal buffer (pH 7.6) and separated into two protein fractions. The first fraction is colorless and the second is yellow. The enzyme activity was found only in the colorless protein fraction. The purified carboxypeptidase $(93 \mathrm{ml}$, protein $270 \mathrm{mg}$, total units 770$)$ obtained in this manner could be preserved at $5^{\circ} \mathrm{C}$ in $0.01 \mathrm{M}$ Veronal buffer ( $\mathrm{pH} 7.6$ ). These procedures resulted in a 25fold purification with an over-all recovery of activity of $15 \%$. Purified carboxypeptidase was homogeneous on ultracentrifugation.

\section{RESULTS}

Screening of peptidase-producing microorganisms

Among about 1300 cultures of microorganisms examined, Streptomyces sp. KY 
Table I. Aminopeptidase and Carboxypeptidase Activities of Culture Filtrates of VARIOUS Microorganisms TESTED

The cultivation was carried out at $30^{\circ} \mathrm{C}$ for $60 \mathrm{hr}$ on a rotary shaker, in $50 \mathrm{ml}$ of the SBM-medium. The aminopeptidase and carboxypeptidase activities of the culture broth were measured under the standard assay conditions.

\begin{tabular}{|c|c|c|}
\hline Strain & $\begin{array}{l}\text { Amino } \\
\text { peptidase } \\
\text { activity }\end{array}$ & $\begin{array}{l}\text { Carboxy } \\
\text { peptidase } \\
\text { activity }\end{array}$ \\
\hline $\begin{array}{l}\text { Streptomyces } \\
\quad \text { flavochromogenes }\end{array}$ & $\begin{array}{l}(\mathrm{u} / \mathrm{ml}) \\
0.045\end{array}$ & $\begin{array}{l}(\mathrm{u} / \mathrm{ml}) \\
0\end{array}$ \\
\hline S. halstedii & 0.072 & 0 \\
\hline S. phaeochromogenes & 0.095 & 0 \\
\hline S. oidiosporus & 0.056 & 0 \\
\hline S. citreus & 0.14 & 0 \\
\hline S. erythreus & 0.041 & 0 \\
\hline S. flavoviridis & 0.049 & 0 \\
\hline S. globisporus & 0.24 & 0 \\
\hline S. fradiae & 0.20 & 0.13 \\
\hline S. filamentus & 0 & 0.13 \\
\hline S. griseolus & 0 & 0.10 \\
\hline S. griseoflavus & 0 & 0.11 \\
\hline $\begin{array}{l}\text { S. peptidofaciens } \\
\text { KY } 2389\end{array}$ & 0.85 & 1.80 \\
\hline S. sp. KY 1510 & 0.48 & 0.38 \\
\hline S. sp. KY 1065 & 0.75 & 0 \\
\hline S. sp. KY 1340 & 0.25 & 0 \\
\hline Aspergillus melleus & 0.54 & 0 \\
\hline A. flavus & 0.21 & 0 \\
\hline A. oryzae & 0.06 & 0 \\
\hline A. effusus & 0.45 & 0 \\
\hline A. ochraceus & 0.06 & 0 \\
\hline A. sclerotirum & 0.07 & 0 \\
\hline Ustilago tritici & 0.08 & 0 \\
\hline Penicillium lilacinum & 0 & 0 \\
\hline$P$. nigricans & 0 & 0 \\
\hline P. brunneum & 0 & 0 \\
\hline P. casei & 0 & 0 \\
\hline Rhizopus acetoinus & 0 & 0 \\
\hline R. chinensis & 0 & 0 \\
\hline R. tritici & 0 & 0 \\
\hline Bacillus subtilis & 0.03 & 0 \\
\hline B. stearothermophillus & 0.03 & 0 \\
\hline B. natto & 0.01 & 0 \\
\hline B. licheniformis & 0 & 0 \\
\hline
\end{tabular}

2389 exhibited the most remarkable activities of aminopeptidase and carboxypeptidase, but almost no activity of proteinase in the culture fluid (Table I). Therefore, this Streptomyces sp. KY 2389 was selected for further investigation.

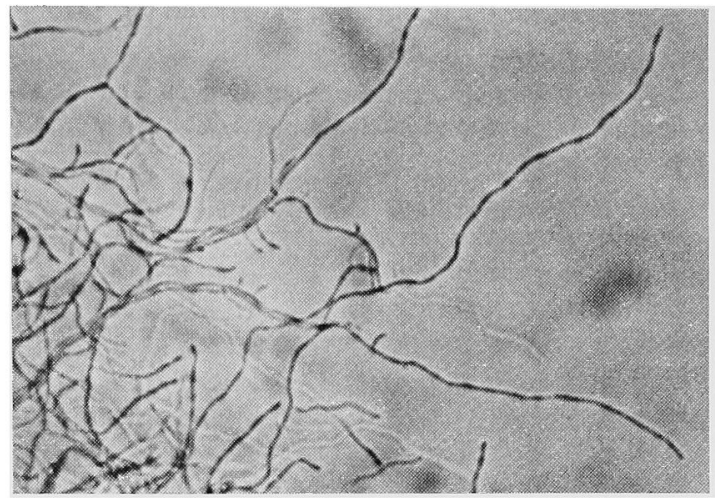

FIG. 1. Microscopic Photograph of Aerial Mycelia of S. peptidofaciens. $(\times 600)$

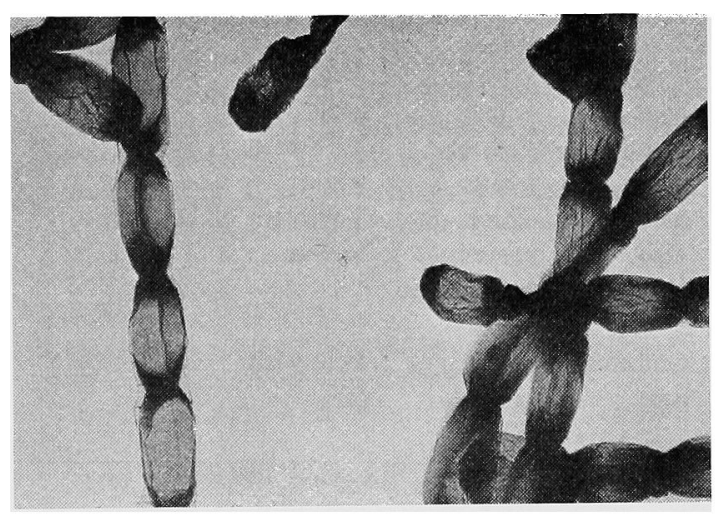

FIG. 2. Electronmicrograph of Conidia of S. peptidofaciens. $(\times 5,000)$

Taxonomical studies on Streptomyces sp. KY 2389

An aerial mycelium of Streptomyces sp. KY 2389 on the synthetic media, exhibits a linear, monopodialy branching structure, sometimes with a slight curvature (Fig. 1). The conidia are formed in chains of more than ten spores. The spores are cylindrical, $0.7 \sim 0.8 \mu \times 1.0 \mu$, with smooth surface (Fig. 2).

The cultural and physiological characteristics of Streptomyces sp. KY 2389 are listed in Tables II and III. The utilizations of carbon sourses of the strain are shown in Table IV.

Among many species of Streptomyces described in "Bergey's Manual of Determinative Bacteriology,"15) and "The Actinomycetes," Vol. 2,16) Streptomyces sp. KY 2389 appeared to be somewhat related to Streptomyces 
Table II. Cultural Properties of S. peptidofaciens

$S$. peptidofaciens was inoculated on each agar medium as indicated and incubated at $27^{\circ} \mathrm{C}$ for 4 weeks.

\begin{tabular}{|c|c|c|c|}
\hline Medium & $\begin{array}{c}\text { Aerial } \\
\text { mycelium }\end{array}$ & $\begin{array}{l}\text { Vegetative } \\
\text { mycelium }\end{array}$ & $\begin{array}{l}\text { Soluble } \\
\text { pigment }\end{array}$ \\
\hline $\begin{array}{l}\text { Synthetic } \\
\text { agar }\end{array}$ & $\begin{array}{l}\text { Thick, dry, } \\
\text { grey }\end{array}$ & Brown & $\begin{array}{l}\text { Brownish } \\
\text { yellow }\end{array}$ \\
\hline $\begin{array}{l}\text { Glucose- } \\
\text { asparagine } \\
\text { agar }\end{array}$ & Thick, grey & $\begin{array}{l}\text { Brownish } \\
\text { grey }\end{array}$ & Pale brown \\
\hline $\begin{array}{l}\text { Glycerine- } \\
\text { asparagine } \\
\text { agar }\end{array}$ & $\begin{array}{l}\text { Pinkish } \\
\text { white }\end{array}$ & $\begin{array}{l}\text { Yellowish } \\
\text { grey }\end{array}$ & Brown \\
\hline $\begin{array}{l}\text { Starch } \\
\text { agar }\end{array}$ & $\begin{array}{l}\text { Thick, } \\
\text { greyish or } \\
\text { pinkish } \\
\text { white }\end{array}$ & $\begin{array}{l}\text { Yellowish } \\
\text { grey }\end{array}$ & $\begin{array}{l}\text { Pale } \\
\text { yellowish } \\
\text { brown }\end{array}$ \\
\hline $\begin{array}{l}\text { Tyrosine } \\
\text { agar }\end{array}$ & $\begin{array}{l}\text { Greyish } \\
\text { white }\end{array}$ & $\begin{array}{l}\text { Yellowish } \\
\text { grey }\end{array}$ & Black \\
\hline $\begin{array}{l}\text { Bouillon } \\
\text { agar }\end{array}$ & $\begin{array}{l}\text { Pinkish } \\
\text { white }\end{array}$ & $\begin{array}{l}\text { Yellowish } \\
\text { white }\end{array}$ & Brown \\
\hline $\begin{array}{l}\text { Yeast-malt } \\
\text { agar }\end{array}$ & $\begin{array}{l}\text { Thick, dry, } \\
\text { greyish } \\
\text { or pinkish } \\
\text { white }\end{array}$ & $\begin{array}{l}\text { Yellowish } \\
\text { brown }\end{array}$ & Dark brown \\
\hline $\begin{array}{l}\text { Oat meal } \\
\text { agar }\end{array}$ & $\begin{array}{l}\text { Greyish or } \\
\text { pinkish } \\
\text { white }\end{array}$ & $\begin{array}{l}\text { Yellowish } \\
\text { grey }\end{array}$ & Dark brown \\
\hline
\end{tabular}

Table III. Physiological Properties of S. peptidofaciens

$\begin{array}{lc}\text { Exopeptidase activity } & + \\ \text { Endopeptidase activity } & - \\ \text { Milk coagulation } & - \\ \text { Milk peptonization } & + \\ \text { Melanine formation } & + \\ \text { Tyrosinase activity } & + \\ \text { Nitrate reduction } & + \\ \text { Gelatin liquefaction } & + \\ \text { Catalase activity } & + \\ \text { Starch hydrolysis } & + \\ \text { Cellulolytic activity } & - \\ \text { Temperature for growth } & 20 \mathrm{C} \sim 37^{\circ} \mathrm{C}\end{array}$

melanogenes from morphological and physiological characteristics, but some differences were found among them, described as follows.

1) Streptomyces sp. KY 2389 utilized rhamnose, although $S$. melanogenes does not.

2) Tyrosinase production by Streptomyces sp. KY 2389 is positive, but that by $S$. melanogenes is negative.
TAble IV. Utilization of Carbohydrates by S. peptidofaciens

Utilization of carbon sources by $S$. peptidofaciens was determined by cultivation on Pridham and Gottlieb's media ${ }^{10}$, which contain $1 \%$ of various carbon compounds as indicated.

\begin{tabular}{lc}
\hline Carbohydrates & Utilization \\
\hline D-Arabinose & + \\
D-Xylose & + \\
D-Glucose & + \\
Sucrose & + \\
Inositol & + \\
D-Rhamnose & + \\
Raffinose & + \\
D-Mannitol & + \\
\hline
\end{tabular}

3) Streptomyces sp. KY 2389 produces aminopeptidase and carboxypeptidase, although $S$. melanogenes does not.

4) Streptomyces sp. KY 2389 does not produce proteinase, although $S$. melanogenes produces it.

From these definite differences, it was concluded that Streptomyces sp. KY 2389 should be assigned to a new strain and designated as Streptomyces peptidofaciens.

Time course of peptidase production

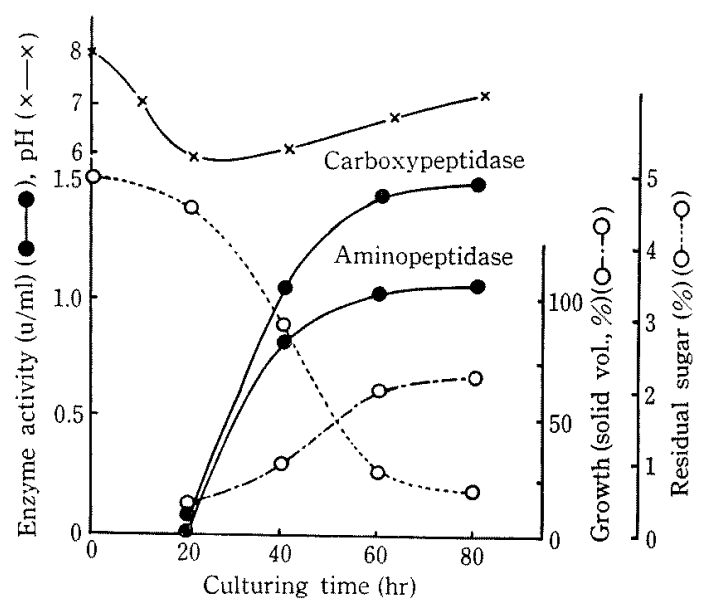

Fig. 3. Time Course of Cell Growth and Peptidase Production during Cultivation of $S$. peptidofaciens with SBM-medium.

S. peptidofaciens was cultivated in 15 liters of the SBM-medium at $30^{\circ} \mathrm{C}$ in a jar fermenter. The aminopeptidase and carboxypeptidase activities of the culture broth were measured under the standard assay conditions. 


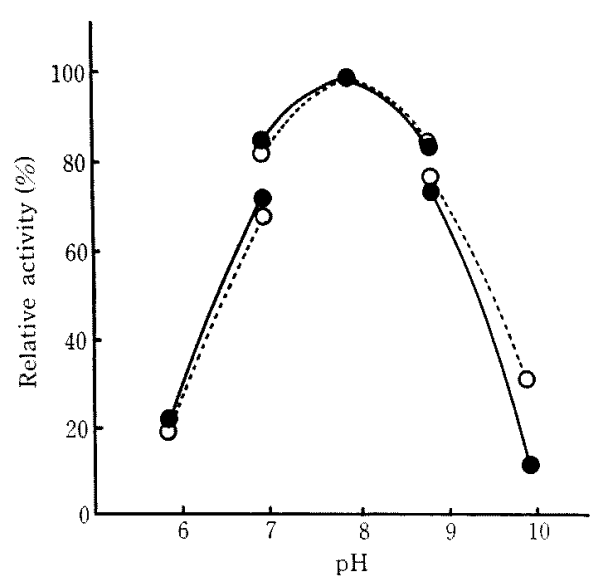

FIG. 4. pH-activity Curves of Aminopeptidase and Carboxypeptidase.

Crystalline aminopeptidase with a specific activity of 69.7 and purified carboxypeptidase with a specific activity of 2.5 were used. The enzyme activity was determined under the standard assay conditions except that $\mathrm{pH}$ of the buffer was changed as indicated. The buffer solutions used were $0.05 \mathrm{M}$ phosphate buffer for $\mathrm{pH} 6 \sim 7,0.05 \mathrm{M}$ Veronal buffer for $\mathrm{pH} 7 \sim 9$ and $0.05 \mathrm{M}$ phosphate- $\mathrm{NaOH}$ buffer for $\mathrm{pH} 9 \sim 10$. -- Aminopeptidase; $\bigcirc--0$, Carboxypeptidase.

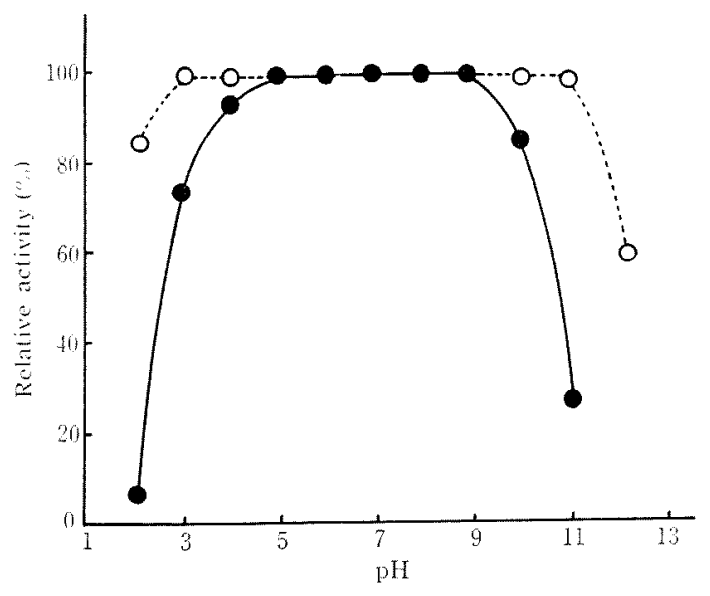

Fig. 5. pH-stability Curves of Aminopeptidase and Carboxypeptidase.

The peptidase (crystalline aminopeptidase containing $24 \mu \mathrm{g}$ of protein and 1.7 units or purified carboxypeptidase containing $225 \% \mathrm{~g}$ of protein and 0.56 units) was kept for $1 \mathrm{hr}$ at $37^{\circ} \mathrm{C}$ in $1.0 \mathrm{ml}$ of $0.05 \mathrm{M}$ buffer solution of various $\mathrm{pH}$ values. The remaining enzyme activity was measured under the standard assay conditions. The buffer solutions used were acetate- $\mathrm{HCl}$ buffer for $\mathrm{pH} 2 \sim 5$, phosphate buffer for pH $6 \sim 7$, Veronal buffer for $\mathrm{pH} 8 \sim 9$ and phosphate$\mathrm{NaOH}$ buffer for $\mathrm{pH} 10 \sim 12$.

-- Aminopeptidase, O--O, Carboxypeptidase

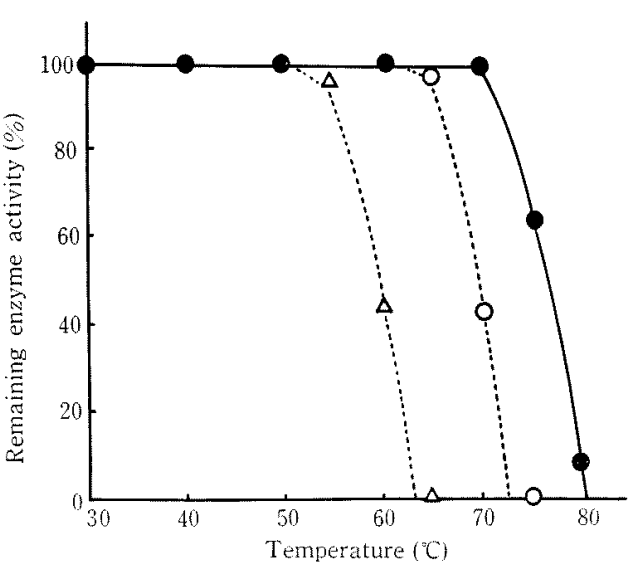

FIG. 6. Heat Stability Curves of Aminopeptidase and Carboxypeptidase.

The peptidase (crystalline aminopeptidase containing $24 \mu \mathrm{g}$ of protein and 1.7 units, or purified carboxypeptidase containing $225 \mu \mathrm{g}$ of protein and 0.56 units) in $1.0 \mathrm{ml}$ of $0.01 \mathrm{M}$ Veronal buffer, $\mathrm{pH} 8.0$, was incubated for $1 \mathrm{hr}$ at various temperatures as indicated. In the case of aminopeptidase, the incubation was performed in the presence or absence of $10^{-3} \mathrm{M} \mathrm{Ca}^{2+}$ The remaining enzyme activity was assayed under the standard assay conditions.

--- 0 , Aminopeptidase, -0 , Aminopeptidase + $10^{-3} \mathrm{M}$ Ca-acetate; $\triangle--\triangle$, Carboxypeptidase.

The chemical changes in the fermentation in relation to the peptidase production were investigated with $S$. peptidofaciens. S. peptidofaciens was inoculated in 15 liters of the SBM-medium. Cultivation was carried out at $30^{\circ} \mathrm{C}$ for $80 \mathrm{hr}$. At every $5 \mathrm{hr}$ intervals, the cell growth, the residual sugar and peptidase activity were determined. The maximum production of both peptidases was observed coincidently at the stationary phase of the cell growth (Fig. 3).

Some properties of peptidase from S. peptidofaciens

Optimum $p H$. The $\mathrm{pH}$-activity curves of aminopeptidase and carboxypeptidase are shown in Fig. 4. Both enzymes exhibit the highest activities at $\mathrm{pH} 8.0$.

$p H$-stability. The pH-stability curves of the enzymes are shown in Fig. 5. The enzymes were kept for $1 \mathrm{hr}$ at various $\mathrm{pH}$ values. Aminopeptidase was stable from 5.0 to 9.0 , 
Table V. Substrate Specificities of AMINOPEPTIDASE AND CARBOXYPEPTIDASE

One $\mathrm{ml}$ of reaction mixture containing $25 \mu$ mole of substrate, $50 \mu$ moles of Veronal buffer, $\mathrm{pH} 8.0$, $48 \mu \mathrm{g}$ of crystalline aminopeptidase (specific activity 69.7 ) or $450 \mu \mathrm{g}$ of purified carboxypeptidase (specific activity 2.5) was kept at $37 \mathrm{C}$ for $30 \mathrm{~min}$. Ca-acetate ( $1 \mu$ mole) was added to the former reaction mixture, and $\mathrm{CoCl}_{2}$ ( $1 \mu$ mole) to the latter. The rate of hydrolysis was measured by the ninhidrin method of S. Moore and W. H. Stein. ${ }^{17}$ The arrows show the peptide bond hydrolyzed.

\begin{tabular}{|c|c|c|c|}
\hline \multicolumn{2}{|c|}{ Aminopeptidase } & \multicolumn{2}{|c|}{ Carboxypeptidase } \\
\hline Substrate & $\begin{array}{l}\text { Rate of } \\
\text { hydrolysis }\end{array}$ & Substrate & $\begin{array}{c}\text { Rate of } \\
\text { hydrolysis }\end{array}$ \\
\hline Leu-Gly-Gly & $100^{a 1}$ & Cbz-Gly-Leu & $100^{b i}$ \\
\hline Leu-Gly & 10 & Cbz-Phe-Leu & 98 \\
\hline Leu-Tyr & 29 & Cbz-Gly-Phe & 98 \\
\hline Leu-Phe & 42 & Cbz-Gly-Val & 65 \\
\hline Leu-NH ${ }_{2}$ & 47 & Bz-Gly-Lys & 60 \\
\hline Phe-Gly & 43 & Cbz-Phe-Tyr & 34 \\
\hline Phe-Leu & 17 & Cbz-Gly-Pro & 0 \\
\hline Gly-Leu & 0 & Cbz-Gly-Trp & 0 \\
\hline Gly-Gly & 0 & Cbz-Lys-Ser & 0 \\
\hline Gly-Gly-Gly & 0 & Cbz-Met-Gly & 0 \\
\hline Ala-Gly & 0 & & \\
\hline
\end{tabular}

whereas carboxypeptidase was stable from 3.0 to 11.0 .

Thermostability. Figure 6 shows the heat stability of each peptidase. Aminopeptidase was stable below $60^{\circ} \mathrm{C}$ by treatment for $1 \mathrm{hr}$ and became stable up to $70^{\circ} \mathrm{C}$ in the presence of $10^{-3} \mathrm{M} \mathrm{Ca}^{2+}$ On the other hand, carboxypeptidase was heat-labile and inactivated over $50 \%$ by incubation at $60 \mathrm{C}$ for $1 \mathrm{hr}$.

Substrate specificity. Substrate specificity of each peptidase was determined (Table V). Among numerous synthetic peptides tested, Leu-Gly-Gly and Cbz-Gly-Leu were the best substrates for aminopeptidase and carboxypeptidase, respectively.

\section{DISCUSSION}

Narahashi et $a l^{6}$ reported that the enzyme preparation of $S$. griseus $\mathrm{K}-1$, "Pronase," was a mixture of several proteolytic enzymes including seven proteinases, two aminopeptidases and carboxypeptidase. Morihara et $a .^{7}{ }^{7}$ also reported that $S$. fradiae produced multiple proteolytic enzymes such as keratinase, leucine aminopeptidase and carboxypeptidase.

In the present paper, the production of aminopeptidase and carboxypeptidase by $S$. peptidofaciens was reported. And special mention must be made of the fact that $S$. peptidofaciens excreted substantially no proteinase in the culture medium.

$S$. peptidofaciens appeared to resemble somewhat $S$. melanogenes from morphological and physiological characteristics. The former was however found not to be identical with the latter in some physiological properties, such as rhamnose utilization, tyrosinase activity and protease productivity.

Aminopeptidase from $S$. peptidofaciens was thermostable and showed a wide range of $\mathrm{pH}$ stability. The enzyme most rapidly hydrolyzed substrates which possess $\mathrm{N}$-terminal amino acid residues containing aliphatic side chains, less rapidly those with aromatic sidechains, while did not hydrolyze those with no side-chains.

On the other hand, carboxypeptidase from $S$. peptidofaciens was heat-labile, although it had a wider range of $\mathrm{pH}$ stability. The enzyme most rapidly hydrolyzed substrates of which C-terminal residues are aliphatic and aromatic, and less rapidly hydrolyzed those of which the terminal are basic.

\section{REFERENCES}

1) V. M. Volgt, J. Biol. Chem., 245, 4760 (1970).

2) N. Minamiura, Y. Matsumura, T. Yamamoto and J. Fukumoto, Agr. Biol. Chem., 33, 653 (1969).

3) J. M. Prescott, S. H. Wilkes, F. W. Wagner and K. Wilson, J. Biol. Chem., 246, 1956 (1971).

4) A. A. Burgum and J. M. Prescott, Arch. Biochem. Biophys., 111, 391 (1965).

5) E. Ichishima, Biochim. Biophys. Acta, 258, 274 (1972).

6) Y. Narahashi, K. Shibuya and M. Yanagita, $J$. Biochem., 64, 427 (1968). 
7) K. Morihara, T. Oka and T. Hiroshige, Biochem. Biophys. Acta, 139, 382 (1967).

8) K. Mizusawa, E. Ichishima and F. Yoshida, Appl. Microbiol., 17, 366 (1969).

9) T. Uwajima, N. Yoshikawa and O. Terada, Agr. Biol. Chem., 36, 2047 (1972).

10) T. G. Pridham, C. W. Hesseltine and D. Gottlieb, J. Bacteriol., 56, 107 (1948).

11) J. A. Goldbarg and A. M. Rutenburg, Cancer, 11, 283 (1958).

12) E. W. Yemm and E. C. Cocking, Analyst, 80, 209 (1955).
13) B. Hagihara H. Matsubara, M. Nakai and K. Okunuki, J. Biochem., 45, 185 (1958).

14) F. A. Loewus, Anal. Chem., 24, 219 (1952).

15) R. S. Breed, E. G. D. Murray and N. R. Smith, "Bergey's Mannual of Determinative Bacteriology," 7th Ed., Williams and Wilkins Co., 1957.

16) S. A. Waksman, "The Actinomycetes," Vol. II, Williams and Wilkins Co., 1961.

17) S. Moore and W. H. Stein, J. Biol. Chem., 176, 376 (1948). 